while they are attending classes! The corridor floors are covered with grey mottled rubber to render the movement of students as silent as possible, and supplementary to the main staircases, passenger lifts have been installed.

It was John Ruskin who wrote, many years ago, "The entire object of true education is to make people not merely do the right things but enjoy the right things". Yet, the pioneers of technical education were mainly concerned with providing a training which was severely utilitarian. But, as Dr. H. Lowery, the principal of the College, aptly points out, "A now problem . . . has arisen-it becomes necessary to provide training for leisure as well as for vocation". Here then is a new function implying heavy responsibilities for the modern college. It is essential to recognize and to cater for the proper use of leisure, and here, in this magnificent new institution, ample opportunities are afforded for developing the true recreational and communal spirit. To quote
Dr. Lowery again, "it is our desire that the College shall become one great educational and recreational community centre where men and women may meet in their leisure time for the purpose of engaging in matters of common interest, thereby securing the fullest opportunity for self-expression".

The material building of this huge college has been very efficiently carried out by the general contractors, Messrs. F. R. Hipperson and Son, Ltd., of London, to the plans of Mr. J. Stuart, the architect, but an even greater work will now be undertaken by the principal and his large staff in laying the foundations of another edifice which will undoubtedly reveal itself in the trained mind, skilled craftsmanship, cultured recreation and, what is most important of all, trustworthiness and reliability of character. As R. W. Dale once wrote: "The immediately possible is hardly worth living for. It is the ideal that kindles enthusiasm and gives inspiration and vigour to all human effort".
F. G. W. B.

\title{
Peneplains and Related Land Forms
}

$I^{\mathrm{T}}$ is now nearly fifty years since W. M. Davis introduced the term 'peneplain' for the surface of low relief which might be expected to mark the end-stages of a long period of sub-aerial erosion under stable conditions. The term was received with a certain suspicion and lack of cordiality among British workers and it has been used comparatively little in their writings. Geographers and geomorphologists will therefore note with interest that the Geological Society recently discussed some of the questions at issue.

In introducing the subject, Dr. F. Dixey's main contention was that the term 'peneplain' is properly applicable to local areas which, though extensive, are far from being of continental dimensions. The common presentation of a cycle of erosion as running its course in a region of homogeneous rocks and resulting ultimately in the base-levelling of a whole land mass leads, in his view, to an unwarrantable attempt to limit the application of the term peneplain. He directed attention to the "two-peneplain topography" described by A. D. Coombe in Uganda, and common indeed throughout Africa, and he showed that such conditions must inevitably arise where weak and resistant rock-masses are juxtaposed. The lower surface opened out in weaker rocks, such, for example, as infaulted strips of Karroo sediments, may have the characteristics of a true peneplain, even though locally interrupted by residual masses and abutting elsewhere against steep slopes. Thus there arose veritable flights of peneplains as between the northern end of the Nyasa rift and the Luangwa valley. Here the following erosion surfaces are distinguishable: a late Jurassic surface at about 7,000 ft., a late Cretaceous or Early Tertiary surface at 5,000 ft., a Miocene surface at 4,000 ft., and a late Tertiary surface developed at about 3,000 ft. on friable Cretaceous rocks in local troughs. Further, a sub-Cretaceous surface has been exhumed locally by erosion and stands at about 2,000 ft. This surface and the late Tertiary surface rank as local peneplains in Dr. Dixey's sense, though others have denied them such rank because they are enclosed by highland areas.

Most other contributors to the discussion expressed agreement with Dr. Dixey, and Mr. J. M. Edmonds described somewhat comparable conditions in the Anglo-Egyptian Sudan. Dr. K. C. Dunham, however, noted that the Rio Grande and the Gila River are flanked by erosion surfaces, up to 80 miles long and 30 miles wide, produced by lateral corrasion. These would apparently rank as local peneplains in Dixey's scheme, but he thought this constituted an extension of the term peneplain and one unlikely to prove acceptable to American workers.

The discussion ranged widely over other cognate matters and several points of view were represented. Prof. O. T. Jones deplored the lack of any agreed definition of the features of a peneplain. He maintained that, in one sense, the whole of England and most of Wales is a peneplain rising gently from sealevel to more than $2,000 \mathrm{ft}$., and truncating all formations from the Pre-Cambrian to the Pliocene. Despite the considerable relief of parts of this surface, such relief can scarcely amount to 10 per cent of the thickness of strata removed by erosion. He also emphasized the probable importance of wind erosion in producing extensive surfaces of low relief.

Other speakers were, by implication at least, unwilling to accept so wide and general a connotation for the term 'peneplain'. Dr. Hollingworth pointed out that Davis's conception of a single peneplain in the Appalachian region is now challenged by several alternative and mutually inconsistent interpretations, most of which agree, at least, in representing the surface as complex and composite. Similarly, Mr. J. F. N. Green expressed the belief that many surfaces in the south of England which might be regarded as peneplains on general inspection have proved susceptible of dissection into distinct terrace-like features, separated by bluffs. Mr. A. A. Miller and Dr. S. W. Wooldridge raised a further issue in pointing out that many of the 'high-level platforms' of Britain, as well as most of the 'fossil' surfaces, 
that is, exhumed planes of unconformity, have been finished, if not formed, by marine agency. In many such cases it is clear that the drainage pattern has not been inherited from a previous cycle, as must inevitably be the case with a true peneplain. Thus, closely spaced wind-gaps in the Old Red Sandstone ridges of southern Ireland indicate a consequent drainage initiated upon the surface which bevelled the structures. Similarly, the transection of anticlinal lines by rivers in southern England indicates that over wide areas the drainage originated upon the emergent floor of a Pliocene sea. Nevertheless, the whole of the region was not submerged; in parts of the Chalk areas of Wessex and the central Wealden area the reconstructed hill-top plane reveals the characteristics of a true peneplain and the drainage was adjusted accordingly. It seems, moreover, that the Thames in earlier stages of its history cut wide benches by lateral corrasion which may fairly be grouped with Crickmay's 'panplains' and the American examples adduced by Dr. Dunham.

The discussion gave a clear indication, if such be needed, that the findings of geomorphology in the field of erosion surfaces now challenge the close attention of the stratigraphical geologist and the geophysicist. Erosion surfaces, some trimmed by marine erosion and others demonstrably of sub-aerial origin, have been proved to have a wide extension and to maintain essentially unwarped attitudes over great distances. As such, they constitute an important record of the later geological history of the continents, supplementing the sometimes scanty evidence of deposition. Further, their existence cannot be ignored by those who seek to understand the nature and extent of isostatic adjustment in the lithosphere.

S. W. WOOLDRIDGE.

\section{Physics in the Textile Industries}

$\mathrm{R}$ ESEARCH physicists working in industry continue to increase in number, and the Institute of Physics, by holding conferences on industrial physics, does much to bring them together to discuss their mutual problems. But the conferences are open to all interested, and the physicist has opportunities of making contacts with those of other professions whose problems are essentially physical.

The third conference, held in Leeds during March 2325, was devoted to "Physics in the Textile Industries". The textile industries have been built up by many years of experimenting coupled with notable inventions, and it has behind it a wealth of knowledge which must be learnt by the physicist if his work is to be of utmost advantage to the industry. Meetings such as that held in Leeds are thus of great value in enabling the physicist to discuss problems not only with other physicists, but also with those conversant with the industry. Simultaneously, the industrial technical man has an opportunity of learning possible applications of physics and physical devices to his industry. This is particularly important for the older textile industries, where few factories have physicists on their permanent staff, and advances which physics has to offer must be introduced and cared for by the technical men.

The conference was held in the Physics Department of the University of Leeds. It was formally opened by the Vice-Chancellor, Mr. B. Mouat Jones, and was presided over by Prof. R. Whiddington. Following established practice of the Institute, the lectures and discussions were informal, and will not all be published.

The formal opening was followed by an address by Prof. Whiddington on "The Physics of Humidity". $\mathrm{He}$ discussed with demonstrations the properties of the small but important amounts of water in the atmosphere, and indicated why relative humidity is for the textile industries a much more convenient measure of the quantity of water vapour in the air than the fundamental measure, vapour pressure. $\mathrm{H}_{\Theta}$ then described properties of substances dependent on water content, and illustrated experimentally the large heat effects associated with change in water content of textile fibres. He concluded with an experi- ment showing the swelling of a wool fibre with increase of water content, using as a micrometer the capacity of a condenser in a heterodyne circuit. Thursday morning's programme was completed by a lecture from Dr. Ezer Griffiths, of the National Physical Laboratory, on "Industrial Humidity Control and Measurement". He illustrated with many slides the requirements of humidifying plant and humidity controls, and described the various ways of measuring relative humidity, indicating the method most convenient to each industrial process where this is important.

The afternoon of March 23 was devoted to a visit to the Department of Textile Industries in the University, followed by Dr. C. C. Paterson's presidential address to the Institute of Physics. He chose as his subject "Colour and Colour Rendering". This was a lecture of exceptionally beautiful and instructive demonstrations. Dr. Paterson pointed out the high efficiency attainable from discharge tube lamps, and contrasted their spectra and colour-rendering properties with daylight and other sources of illumination. The colour triangle and C.I.E. units were simply and elegantly explained, and there followed striking demonstrations of the difference between matched white lights for colour rendering. He pointed out that the appraisement of colour matching value is a pressing but unsolved problem. The lecture concluded with illustrations of the improvement in colour quality and efficiency attainable in discharge tube lamps by use of fluorescent materials.

The lectures on March 24 were by Dr. M. C. Marsh, of the Cambridge Instrument Co., Ltd., who chose "The Contribution of Physics to the Development of Industrial Process Control", and by Mr. D. Harrison, who spoke on "Automatic Regulators for the Textile Industries". These lectures brought to the notice of all the many instruments now available for industry, and features of their design gave an impressive illustration of the potentialities of physical krowledge when applied to industry.

The final lecture of the meeting was on "Heat Effects in Fibres and other Systems". It was given by Dr. C. G. Darwin, director of the National Physical Laboratory. It was a delightful lecture on a difficult 